\title{
Role of lifestyle factors of mothers on the incidence of idiopathic hyperbilirubinemia (jaundice) of their neonates in Tehran
}

\author{
Sahar Naseri ${ }^{1}$, Sepideh Arbabi Bidgoli ${ }^{2}$ \\ ${ }^{I}$ PharmD, Pharmaceutical Sciences Research Center, Tehran Medical Sciences, Islamic Azad University, Tehran, Iran \\ ${ }^{2}$ PharmD, PhD, Professor, Department of Toxicology and Pharmacology, Faculty of Pharmacy and Pharmaceutical \\ Sciences, Tehran Medical Sciences, Islamic Azad University, Tehran- Iran.
}

\begin{abstract}
Background: Hyperbilirubinemia is a neonatal ubiquitous condition but the role of life style factors and endocrine disrupting chemicals (EDCs) on the incidence of this globally prevalent symptoms remained unclear. This study aimed to determine the role of EDCs and other predisposition factors in this regard.

Materials and methods: At first, 120 mothers and infants (60 pairs as control and 60 pairs as cases) were conveniently sampled after delivery and before their discharge. The mothers were interviewed and their case records were reviewed for risk factors for neonatal jaundice using SPSS software 24. We used student's t test for parametric and Chi-square test for non-parametric analysis of variables. Risk factors calculated by MannWhitney $\mathrm{U}$ test and $\mathrm{p}$ - values $<0.05, \mathrm{OR}>1$ and $\mathrm{CI}>1$ were considered as significant difference and jaundice risk factors respectively.

Results: Out of different demographical and lifestyle factors including exposure to outdoor and indoor chemicals, extensive exposure to air fresheners $(\mathrm{OR}=16.319,95 \% \mathrm{CI}=2.06-129.292, \mathrm{p}=0.001)$ and detergents $(\mathrm{OR}=4.958,95 \% \mathrm{CI}=2.074-11.852, \mathrm{p}=0.0001)$ were considered as two major life style predisposing factors of idiopathic hyperbilirubinemia.

Conclusion: According to the results obtained from this study, unhealthy life style and endocrine disrupting chemicals consumption could significantly increase the risk of jaundice but further animal and clinical studies are necessary to find out their direct associations.

Keywords: Lifestyle, Neonates, Jaundice, Idiopathic, Hyperbilirubinemia, Tehran.

Cited as: Naseri S, Arbabi Bidgoli S. Role of Lifestyle Factors of mothers on the Incidence of Idiopathic Hyperbilirubinemia (Jaundice) of their neonates in Tehran. Medical Science Journal of Islamic Azad University, Tehran Medical Branch 2020; 30(4): 443-452.

Correspondence to: Sepideh Arbabi Bidgoli

Tel: +989121776800

E-mail: Sepideharbabi@gmail.com

ORCID ID: 0000-0003-4830-8680

Received: 19 Jun 2019; Accepted: 4 Jun 2020
\end{abstract}


مجله علوم يزشكى دانشعاه آزاد اسلامى

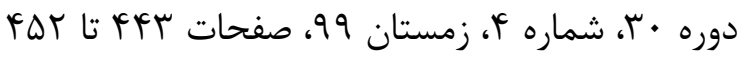

\section{بررسى تاثير سبك زندكى در بروز هاييربيلى روبينمى(زردى) ايديوياتيك نوزادان مادران ساكن تهران

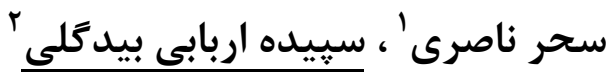

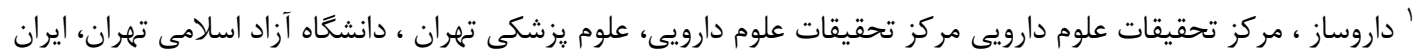

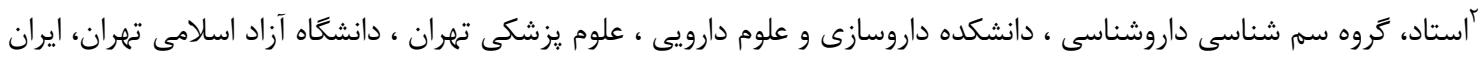

جـكيده سابقه و هدف: با توجه به شيوع هيبربيلى روبينمى /يليوياتيك نوزادان و ناشناخته بودن رابطه بين سبك زندكى و كيفيت بروز

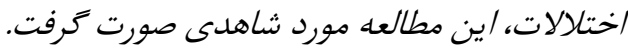

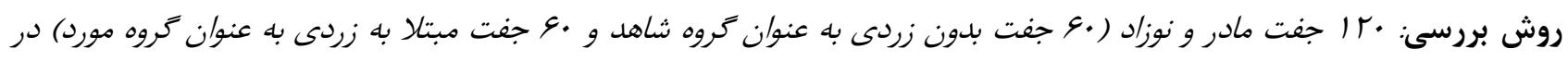

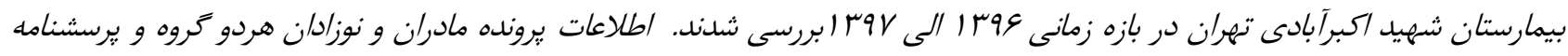

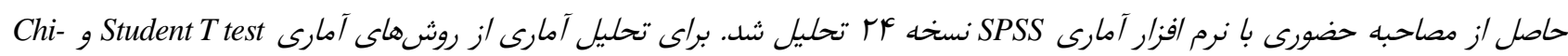
Mann-Whitney U بين كروه مورد و شاهد محاسبه شد.

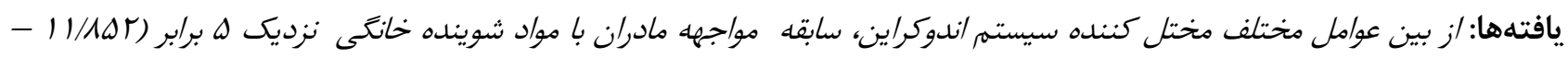

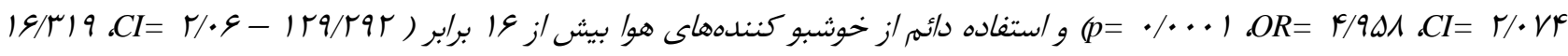
OR=

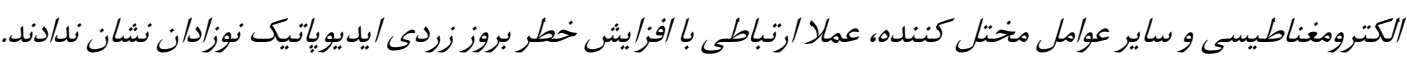

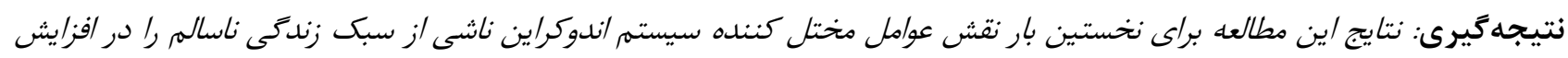

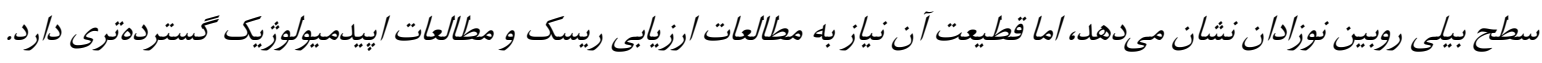
وازَكان كليدى: سبك زندكى، زردى، هيبير بيلى روبينمى، /يديوياتيك، مادران، نوزادان، تهران.

جهان گزارش شده است (Y) . متاسـفانه هييربيلـى روبينمسى

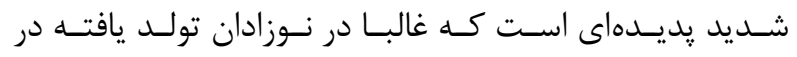

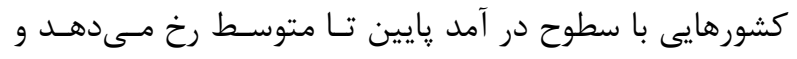

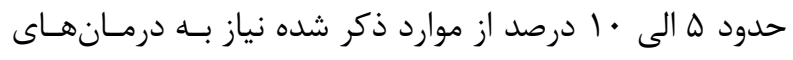

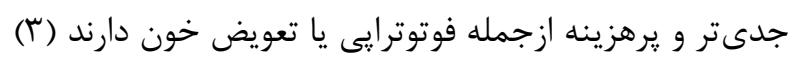

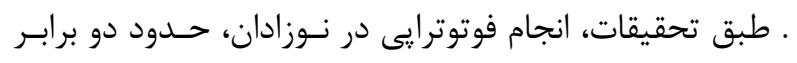

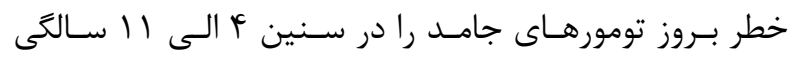

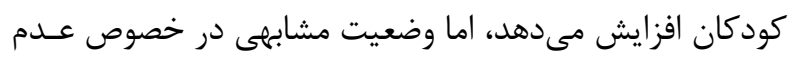

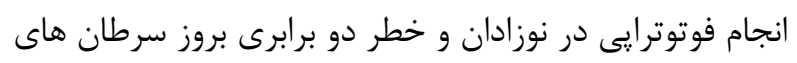

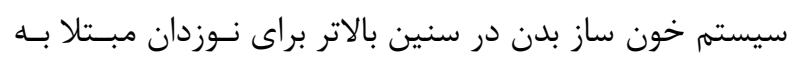

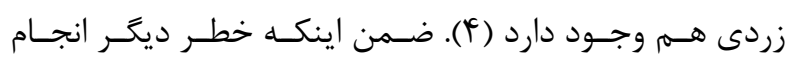

مقلمها

هيبربيليروبينمى يا زردى نوزادان، يكى از مشكلات شايع يـس تهـ

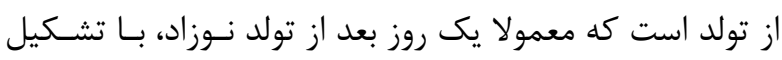

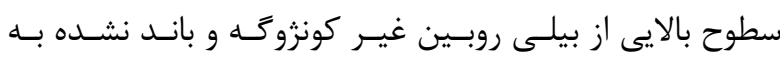

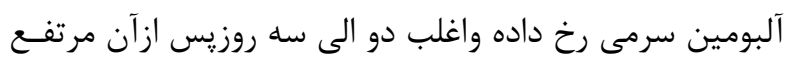
مىشود (1). اترجه آمار دقيقى از ميزان بروز زدردى نــوزادان

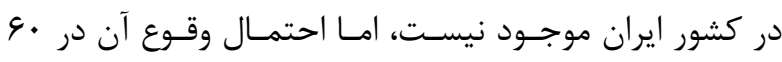
درصد از نوزادان رسيده و • ^ درصد از نوزادان نارس در در سراسر

آَدرس نويسنده مسئول: تهران، كروه سم شناسى داروشناسى ، دانشكده داروسازى و علوم دارويى، سبيده.

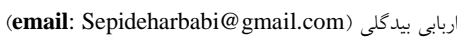
ORCID ID: 0000-0003-4830-8680 تاريخ دريافت مقاله:

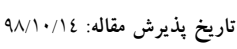


عوامل مختل كننده سيستهم اندوكراين تركيبـاتى هسـتند كـهـ

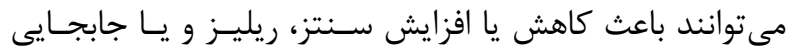
هورمونهاى مختلف بدن شده و عوارضى را به صـورت بـالينى در طول زمان از جمله اختلات جنينى، كاهش ميزان بارورى و

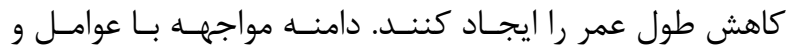
آلايندههاى زيست محيطى مختل كننده سيستم اندوكراين تـا

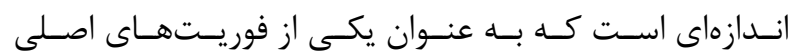

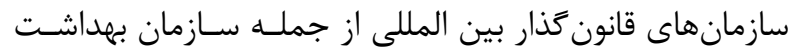
جهانى و آزانس محيط زيست آمريكا قرار زرفتـه اسـت (I (I) .

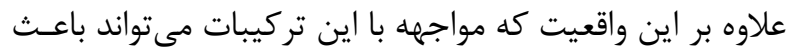

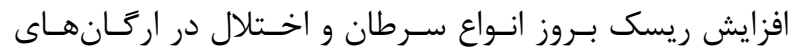
جنسى زن و مرد شده (1/)، احتمال بروز اختلالات تيروئيدى

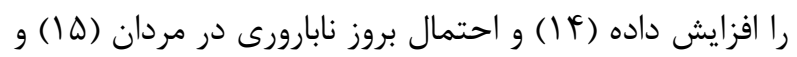

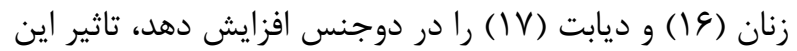

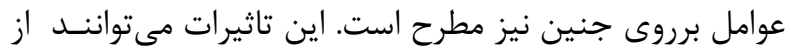

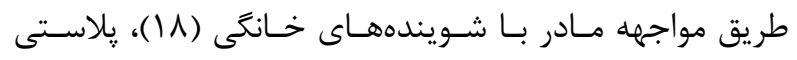

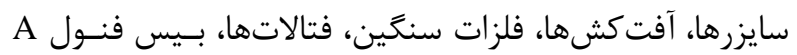
(9 (1) وموارد ديخر متوجه جنين شده، ريسك بــروز اخــتلالات

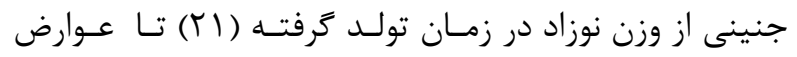
جاقى در نوزادان و كودكان مادرانى كه در معرض اين تركيبات

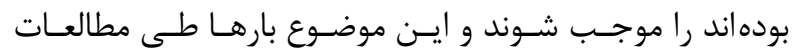

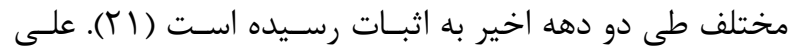

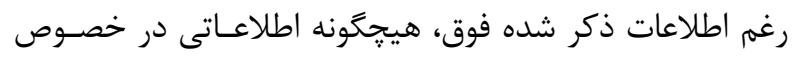
كميت و ميزان دوز اين مواد و بروز اثـرات جنينـى بـهـ انتشــار

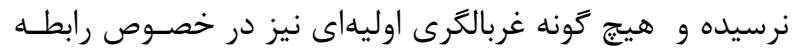

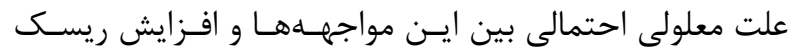

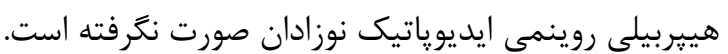

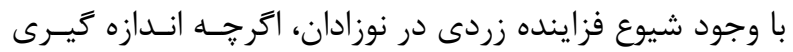

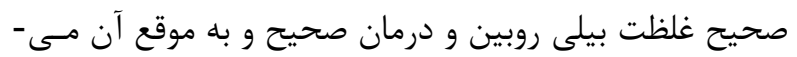

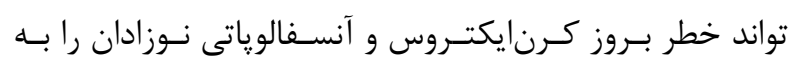
حداقل رسانده و روزانه مرگ هزاران نــوزاد در سـطح جهــان را

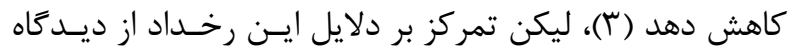

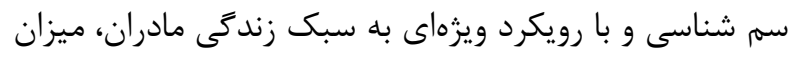

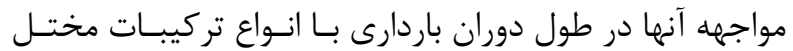

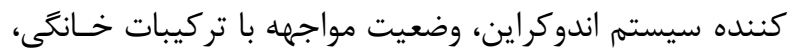

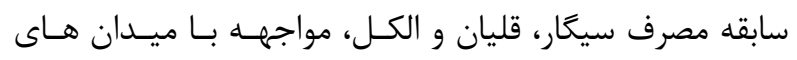

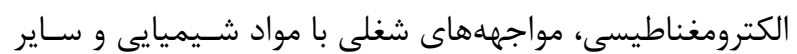

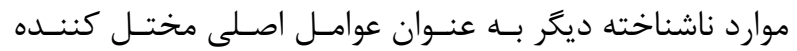

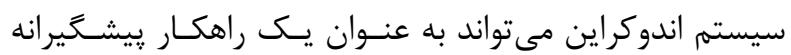

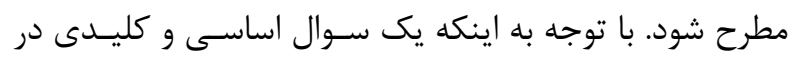

فوتوترايى نوزدان، كاهش سـطح سـرمى كليسـيم و مينـزيهم و بالارفتن غير طبيعى سطح سرمى ويتامين D است(ه). از دلايل شناخته شده و اصلى بروز هيبربيلى روبينمى نوزئى نوادان

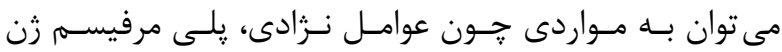

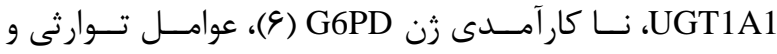
همجنين عوامل اكتسابى از جمله اسفروسـايتوزيس و سـندرم

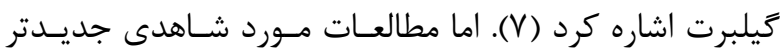

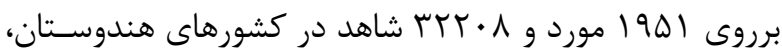
نيجريه، ياكستان، نيال و مصر نقش زايمان اول، زايمان خـارج

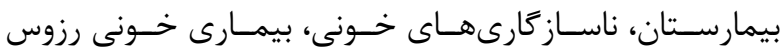
(Rhesus hemolytic disease) نوزاد زودرس و بروز سيسيس را به عنوان عوامل اصـلى بـروز آن بدون در نظر كرفتن وضعيت اقتصـادى و اجتمـاعى مطـرح كردهاند (^). با اين حال، درصد قابل توجهى از موارد هييربيلى روبينمى نوزادان، به عنوان مـوارد ايـديوياتيكى تشـخيص داده

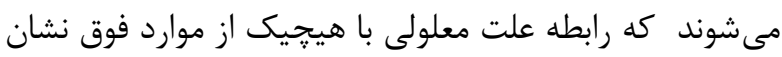

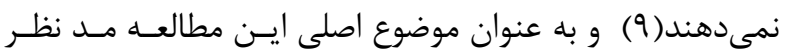
قرار گرفتهاند. با بالارفتن سطح سرمى بيلى روبين غير كونزوگه از حد آسـتانه

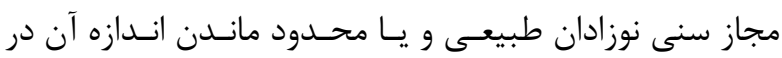

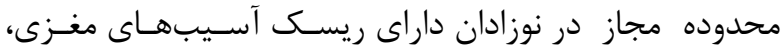
خطر جدى ايجاد اثرات سـمى بـر سيسـتم عصـبى نـوزادان

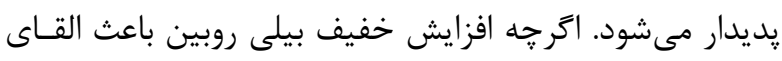

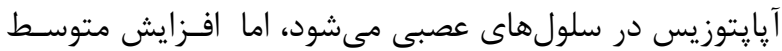

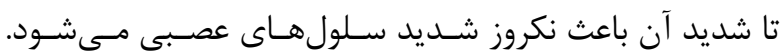
مكانسيهم ييشنهادى براى بروز اين آسيبهـاى سـمى مـذكور،

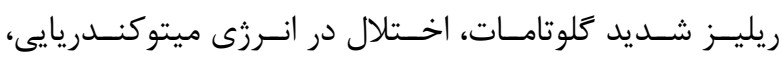
آزادشدن سايتوكاينهاى ييش التهابى و افزايش غلظت كلسيم

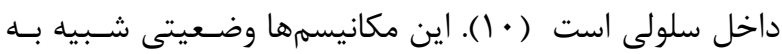
وضيعت ايسكمى هييوكسيك را در نوزاد مبـتلا بـهـ زردى القـا

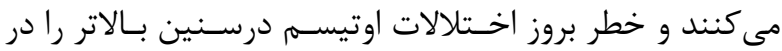

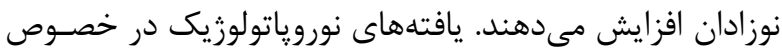
سميت عصبى ناشى از بيلى روبين ،حكايت از القاى آسيبهاى

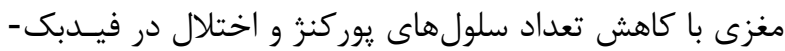
هاى جندحسى بين مخجه و نرونهاى كورتيكال دارد كه مى -

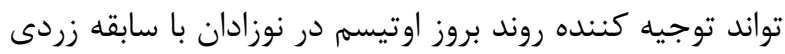

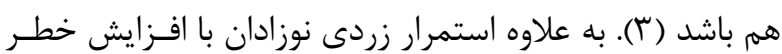
بروز عفونت دستخاه تناسلى در نـوزادان ايرانسى نيـز بـهـ كـرات

گزارش شده است (1 (1). 
r. تشخيص قطعى هييربيليروبينمى در نوزاد بر اساس

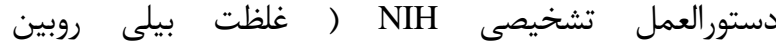

(Brits H 2018) (>1 • • mmol/lit f. ع عدم سابقه خانوادگى زردى يا ناهنجارى مادرزادى ه. عدم سابقه ابتلاى مادر به بيمارىهاى زمينهاى ديخر 9. عدم وجود ناساز كارىهاى خونى مادر و نوزاد V. دسترسى به مادر ورضايت وى جهت مصاحبه و تكميل فرم يرسشنامه موارد زير معيارهاى خروج را تشكيل مىدادند:

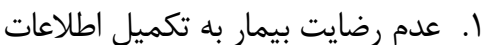
r. سابقه ابتلاى مادر به هر كونه اعتياد،

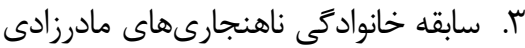

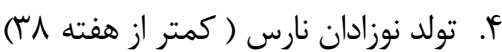
ه. اساز كارىهاى خونى مادر و نوزاد

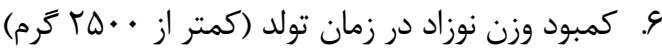

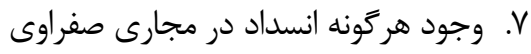

1. اختلالات كولستاتيك وابسته به TPN

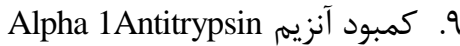
• ا.بيمارى سيستيك فيبروزيس

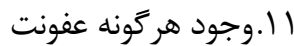

Alagille Syndrome. IT براى تامين اهداف اين مطالعه، يرسشنامه مربوطه طراحى و اعتبـار

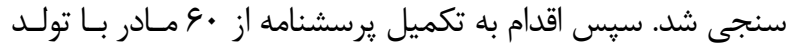

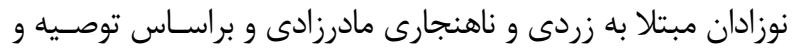

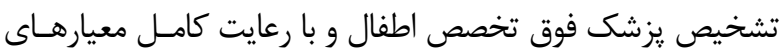
ورود و خروج از مطالعه شد. تعداد .9 يرسشنامه از مادران با تولـد فيد

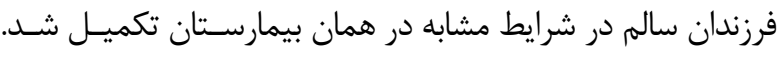

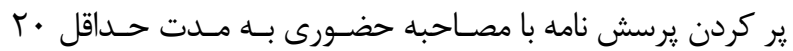

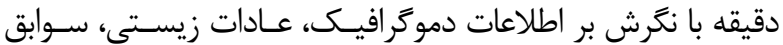

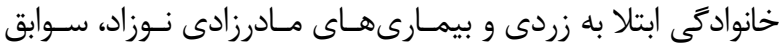

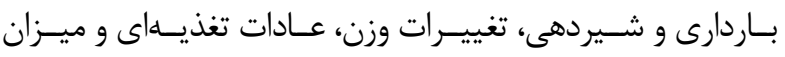

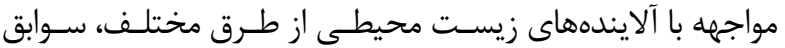

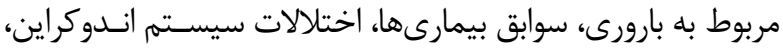

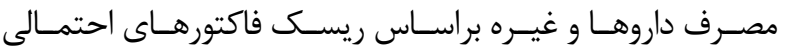
موجوددر منابع جهت اين بيمارى صورت كرفت. ير كردن يرسشنامه با مصـاحبه حضـورى بـر اسـاس فاكتورهـاى ئري دموكر افيك مادران (سن، قد، وزن، افزايش وزن، سوابق بـاردارى و و

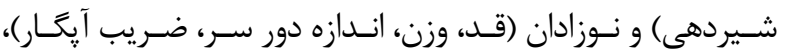

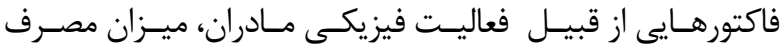

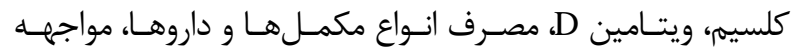

راستاى دلايل بروز فزاينده اين عارضه در نوزادان مغفول بـاقى

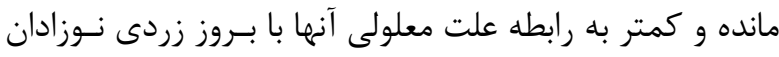
برداخته شده است، هدف از طراحى اين مطالعه ايــن بـود كـهـ سبك زندگى در مادران داراى نوزادان مبتلا هييربيليروبينمسى

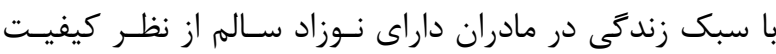

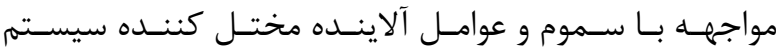

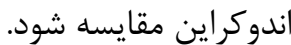

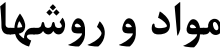

بِ از هماهنكَى با مركز آموزشى درمانى شهيد اكبرآبـادى تهـران

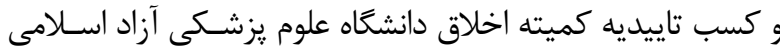

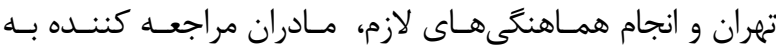

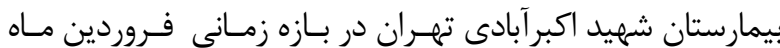

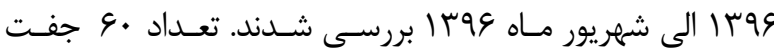

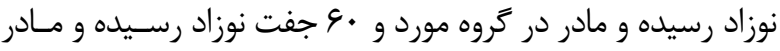
در گروه شاهد مورد مصاحبه و ارزيابى يرونده قرار كرفتند. روش تعيين حجم نمونه : جهت تعيين حجم نمونه تحقيق حاضـر

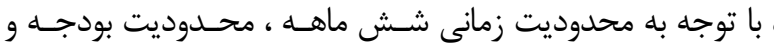

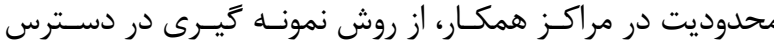

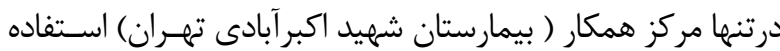

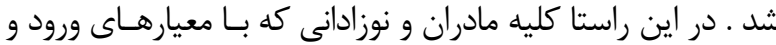
خروج مطالعه مطابقت داشته و مطابق كد اخلاقسى اختصـاص داده

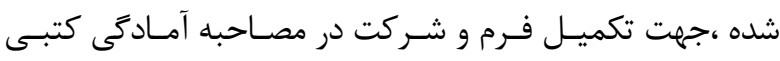
داشتند، وارد مطالعه كرديدند. تخصيص نمونه ها و شاهد هـا: كليـهـ مصـاحبه شـوندههـا مـادران

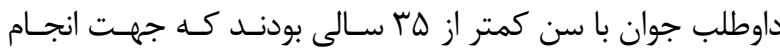
زايمان طبيعى به بيمارستان شهيد اكبر آبادى تهران مراجعه كـرده

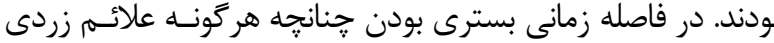

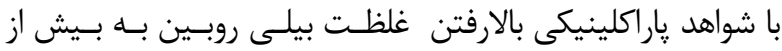

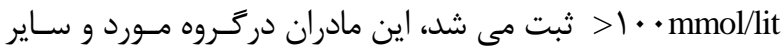

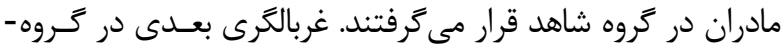
هاى مورد و شاهدى به ترتيب و دوباره بر اساس معيارهـاى ورود و خروج مطالعه به شرح ذيل صورت كرفت. معيارهاى ورود كليه زنان داوطلب جهت شـركت در ايـن مطالعـهـ

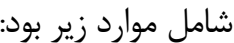

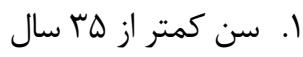

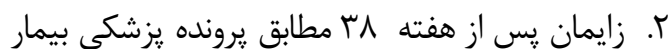


ويزَّى هاى تحصيلى، اقتصادى، اجتماعى و سلامت عمومى مادران و هييربيليروبينمى نوزادان مادران اين مطالعه در هردو گروه مورد و شاهد از نظر تحصيلى، اشتغال، سابقه ابتلا به بيمارىهاى زمينهاى جسمى و روحى و درآمد ماهيانه تفاوت معنى دارى نداشتند. مواجهه با مواد شيميايى و هييربيليروبينمى نوازادان نظافت منزل و استنشاق مواد شوينده فنلى مطابق با جدول r از ميان فاكتورهاى زيست محيطى و

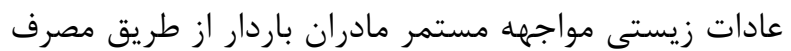
مواد شوينده فنلى در منزل، نزديك به ه برابر خطر بروز

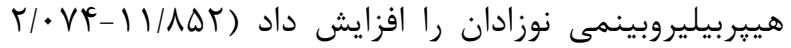

$.(\mathrm{P}=\cdot / \cdots) ، \mathrm{OR}=\mathrm{F} / 9 \Delta \Lambda ، \mathrm{CI}=$

استفاده از اسيرى هاى خوش بو كننده هوا مطابق با جدول r از ميان فاكتورهاى زيست محيطى و عادات زيستى مواجهه مستمر مادران باردار، استفاده مستمر

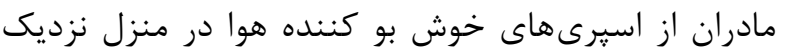

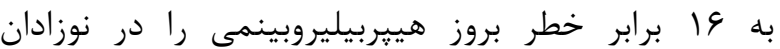
افزايش داد ( OR=

$(\mathrm{P}=\cdot / \cdot)$

مصرف الكل

به جز يكى از مادران گروه مورد، هيجٍدام از مادران دو گروه سابقه مصرف الكل در طول باردارى و قبل از آن نداشتند لذا تاثير اين فاكتور نيز عملا از جهت آمارى درى در

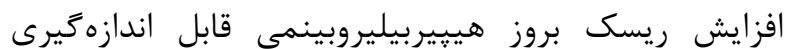

دود سيگًار و قليان

اگرجه تعداد مادران در معرض دود سيگار و قليان اطرافيان

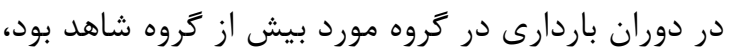

مادران طى باردارى با مواد شـيميايى از جملـه مـواد ضــد عفـونى

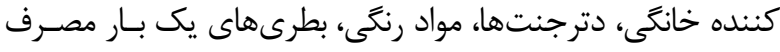
يلاستيكى صورت گرفت. در بخش بعدى، فاكتورهـاى تغذيـهاى از جمله ميزان مصـرف سـبزيجات، حبوبـات، فــرآوردهــاى جـرب، ماهى، روغنهاى جامد و مايع و لبنيات بين دوزروه مقايسـه شـد.

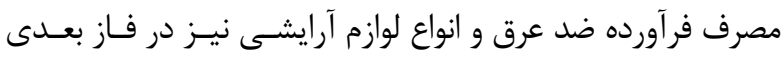
مورد بررسى قرار گرفت كه اين مقاله صرفا بـه تبيـين بخـش اول فاكتورهاى مرتبط با سبك زندگى مادران يرداخت. هِ از تكميل پرسشنامهها به بررسى آمارى و تكميل اطلاعات بـهـ

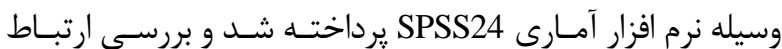

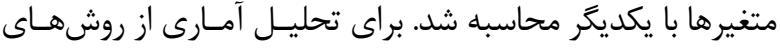
آمـارى Student T test و اسـتفاده شــد و ريسـك فاكتورها با تست Man Witeny U test بين حَروه مـورد و شـاهد محاسبه شد.

كافته ها مقايسه و ويثزى هاى دموزرافيك نوزادان و مادران كروههاى مورد و شاهد همان طوركه در جدول I ذكر شده است، على رغم وجود تفاوت معنى دار در ضريب آيخار بين گروههاى مورد با

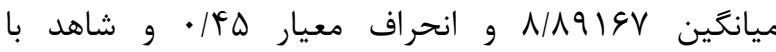

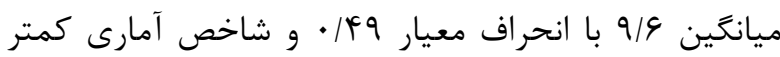
از ا • • • • بين فاكتورهاى قد، وزن، دورسينه و سر نوزدان كروه مورد و شاهد تفاوت آمارى معنىىارى مشاهده نشد.

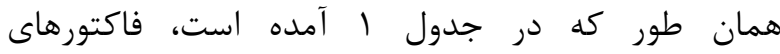
دموگرافيك مادران شامل قد، وزن و سن ازدواج نيز عملا تفاوتى را بين گرووه مورد و شاهد يس از اعمال معيارهاى ورود و خروج نشان ندادند.

جدول ا. ويزگى هاى دموكرافيك مادران و نوزادان مبتلا به هييربيليروبينمى در مقايسه با گروه كنترل

\begin{tabular}{|c|c|c|c|}
\hline p-value & تروه شاهد & تروه مورد & مشخصات نوزادان و مادران \\
\hline$\cdot / 1 \Lambda$. & $r \cdot r \xi / \mid 99 V(r V \cdot / V)$ & $r \mid \Delta \& / \Delta r(\Delta \wedge r / q)^{*}$ & وزن نوزادان (كَرم) \\
\hline$\cdot / \mathrm{Vq}$ & 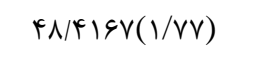 & YN/TYS. $(\Delta / T V)$ & قد نوزاد ( سانتى متر) \\
\hline$\cdot / 1$ & $r r / G \Delta(1 / F \Delta)$ & rT/ATQ(I/VD) & دورسر نوزاد( سانتى متر) \\
\hline ( ) & $r T / F \mid G V(1 / T V)$ & 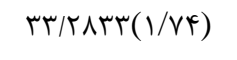 & دور سينه نوزاد ( سانتى متر) \\
\hline$\cdot 1 \cdot \cdot 1^{*}$ & $q / 4 \cdots(\cdot / 4 q)$ & $\wedge / q \mid \& \vee(\cdot / \uparrow \Delta)$ & عدد آيخار, \\
\hline$\cdot, \cdot V r$ & $r \wedge, r r(F / r ı)$ & $r q / \wedge \Delta(r / \wedge \varepsilon)$ & سن مادر س \\
\hline . 1199 & $V V / T(V / F)$ & $V V / F \Delta(I T / V \Delta)$ & وزن مادر ( كيلو مرم) \\
\hline$\cdot|r| 9$ & $|\varepsilon| / V(T / \Delta \varphi)$ & $19 \% / 9 \wedge(r)$ & قد مادر (سانتى متر) \\
\hline$\cdot / T Y \Lambda$ & $r I / \Lambda(F / M r)$ & $r r / V(r / / Q)$ & سن ازدواج \\
\hline
\end{tabular}


جدول r. مقايسه فاكتورهاى زيست محيطى و عادات زيستى درجمعيت مادران داراى نوزاد مبتلا به زردى و جمعيت كنترل

\begin{tabular}{|c|c|c|c|c|c|}
\hline 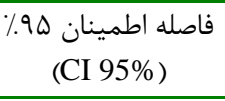 & $\begin{array}{c}\text { نسبت شانس } \\
\text { (OR) }\end{array}$ & P-value & 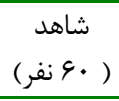 & 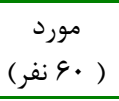 & فاكتورهاى زيست محيطى \\
\hline \multirow{4}{*}{-} & & & & & مواجهه با مواد شيميايى در محيط كار \\
\hline & $\cdot / r V V$ & $\cdot / r \mid \Delta$ & . & r & 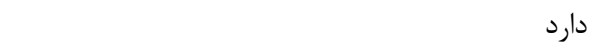 \\
\hline & & & 4. & $\Delta V$ & 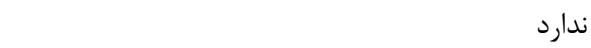 \\
\hline & & & & & سابقه مصرف الكل در باردارى \\
\hline \multirow[t]{3}{*}{$\cdot|F| F-\cdot \mid \Delta q F$} &.$/ 499$ & $\cdot / \pi / \Delta$ & $\cdot$ & 1 & بله \\
\hline & & & c. & $\Delta 9$ & خير \\
\hline & & & & & سابقه مصرف سيخاردر باردارى \\
\hline \multirow[t]{6}{*}{ 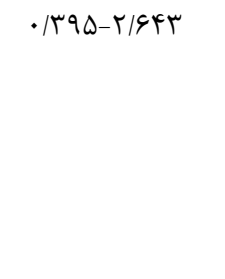 } & $1 / 911$ & $\cdot / r V \cdot$ & is & et & غير سيخارى و اطرافيان غيرسيگارى \\
\hline & & & ir & 11 & غيرسيعارى و اطرافيان سيخارى \\
\hline & & & . & $\cdot$ & ترى سيخاردر باردارى \\
\hline & & & · & · & مصرف تفننى سيحار در باردارى \\
\hline & & & · & $\cdot$ & مصرف مداوم سيگًار در باردارى \\
\hline & & & & & سم پاشى در منزل در دوران باردارى \\
\hline \multirow[t]{3}{*}{ 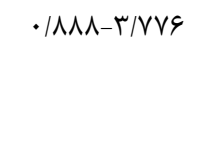 } & I/ArI & $\cdot / 1 \cdot$ & rq & ra & 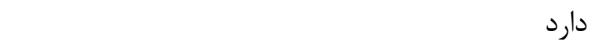 \\
\hline & & & ry & TQ & 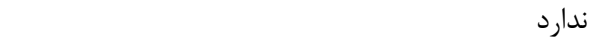 \\
\hline & & & & & استفاده مكرر از دترجنت هاى خانكى در دوران باردارى \\
\hline \multirow[t]{3}{*}{$r / \cdot V F-11 / \Lambda \Delta T$} & $r / 9 \Delta \wedge$ & $* / \cdots 1$ & rt & $\Delta 1$ & دارد \\
\hline & & & rA & 9 & 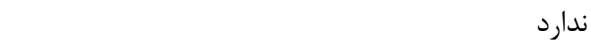 \\
\hline & & & & & سيستم تصفيه هواى منزل \\
\hline \multirow[t]{2}{*}{$r / \cdot G \cdot-1 T 9 / r q T$} & $19 / \pi 19$ & $* 1 \cdot \cdots 1$ & 1 & ir & استفاده دائم از اسيرى خوش بو كننده هوا \\
\hline & & & $\Delta 9$ & FV & ينجره ها \\
\hline
\end{tabular}

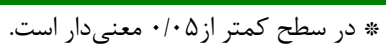

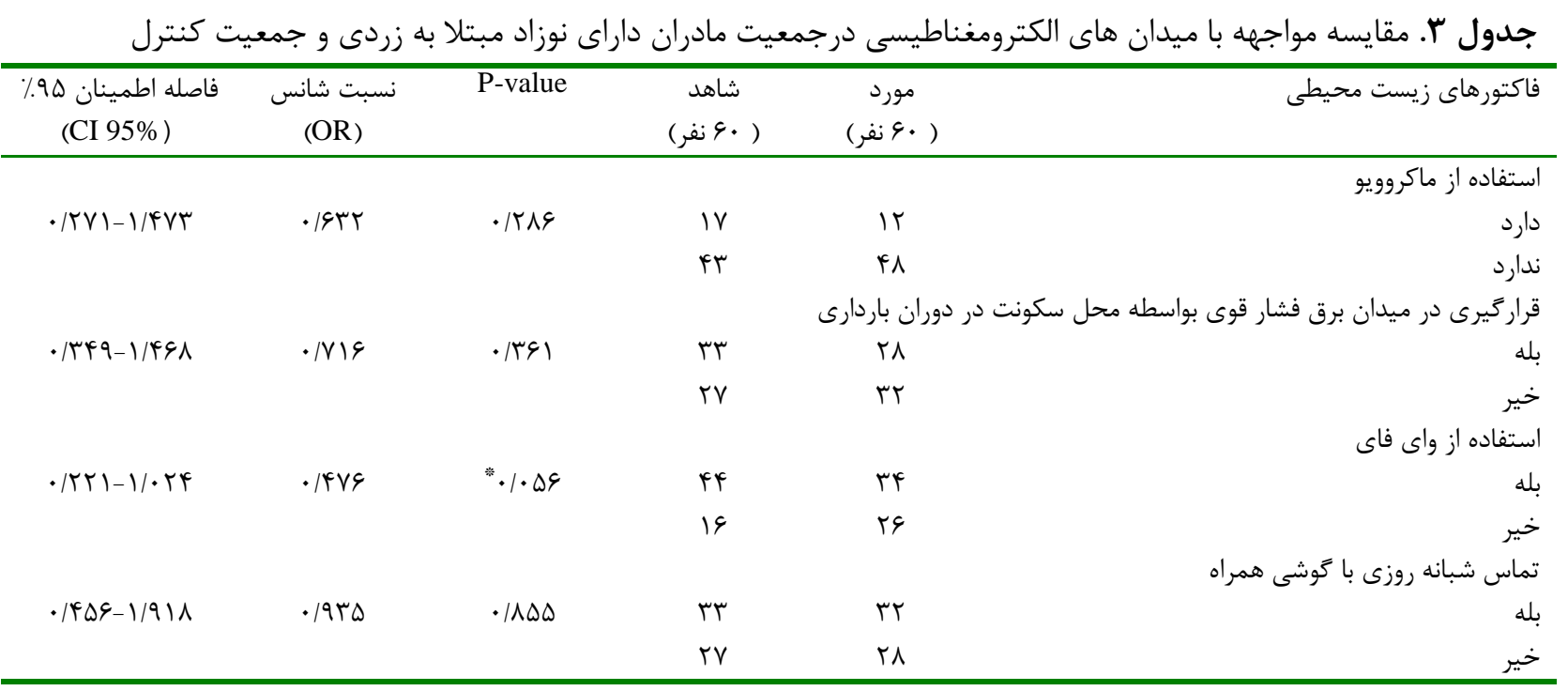

* مر سطح كمتر ازه • • معنى دار است.

جهت آمارى در افزايش ريسك بروز هيييربيليروبينمى نداشت.

قرارگيرى در معرض ميدانهاى الكترومغناطيسى و هيبربيليروبينمى نوازادان همانطوركه در جدول r نمايش داده شده است، اين وضعيت از طريق مقايسه ميزان تماس شبانه روزى مادران
ولى اين وضعيت تفاوت معنى دارى را از نظر آمارى با گروه

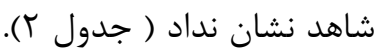
مواجهه شغلى با مواد شيميايى از بين • rا مادر موضوع اين مطالعه در دوگروه مورد و شاهد، صرفا r نفر سابقه مواجهه شغلى با مواد شيميايى داشتند و اين تعداد در مقايسه با جمعيت كل تاثيرى از 
كودكان، سندرمهاى وابسته (كيلبرت) تا آسيبهاى كبدى

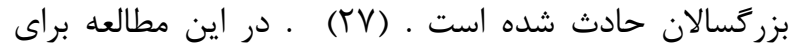

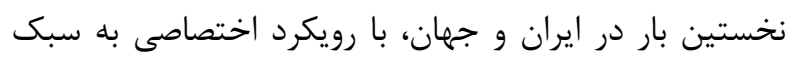
زندگى در • rا جفت مادر و نوزاد با سطح اقتصادى ضعيف در

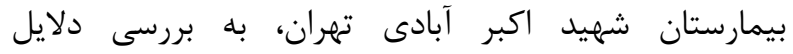

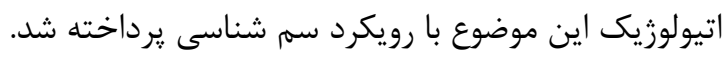

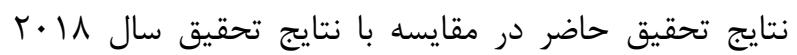

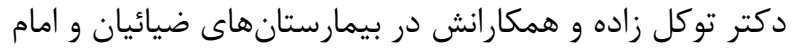

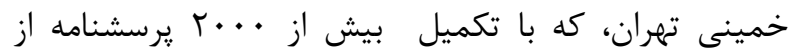

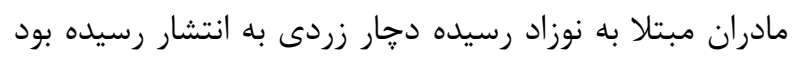
و عواملى جون سن مادران طى باردارى، باردارى اول، تعداد

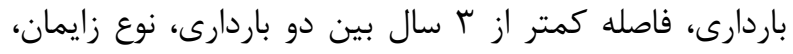

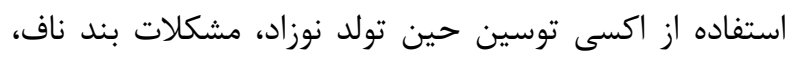

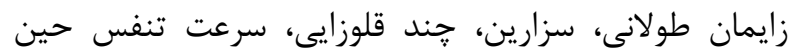

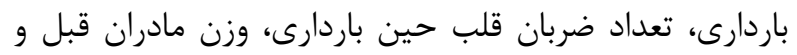

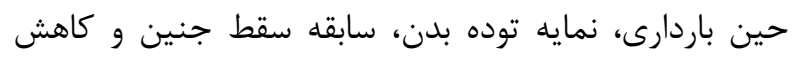
وزن حين باردارى را مد نظر قرار داده بود (r) و و تحقيق تاريق ديكرى در افريقاى جنوبى كه با همين رويكرد، زايمان طبيعى داردى

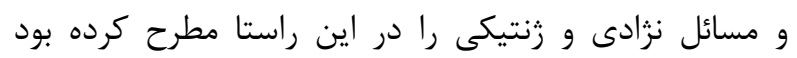

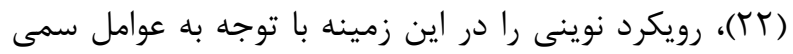

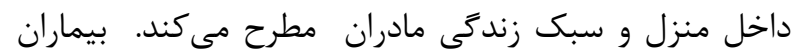

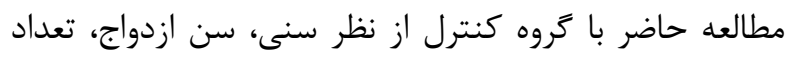

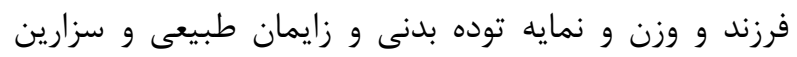

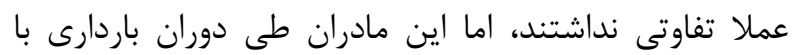
شويندهاى فنلى و خوش بو كنندههاى هوا كه هردو از عوامل

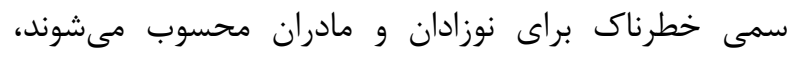

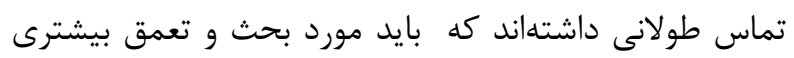

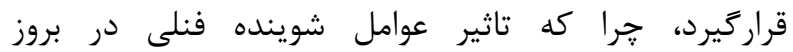

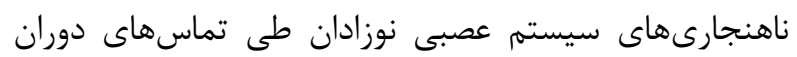

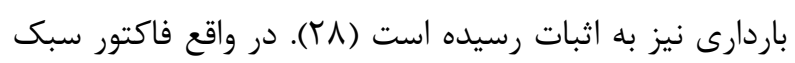

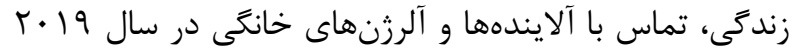

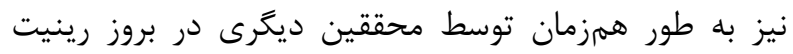

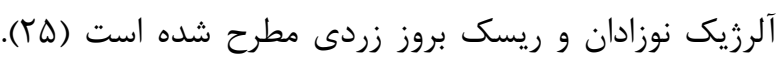
مادران اين مطالعه بيشتر از طبقه فقير جامعه بودند، كه زئه

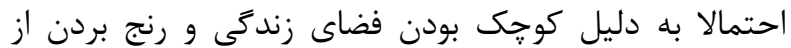
بوهاى نامساعد محيط اطراف به استفاده از خوشبو كننده هوا

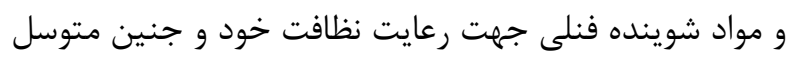
شده بودند و يا اينكه به واسطه كار در منازل و اماكن جهت درآمدزايى به طور جدى ترى در معرض اين مواد بودهاند.
با كوشى همراه، داشتن ماكرو ويو و استفاده از آن، قرار

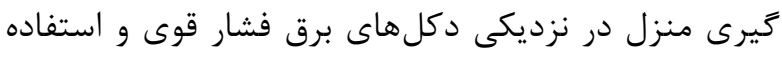

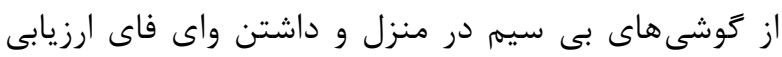

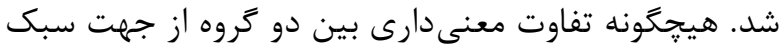
زندكى و قرار كيرى در معرض اين ميدانها مشاهده نشد.

\section{بحث}

تاكنون مطالعات كستردهاى در خصوص نقش عوامل مختل كننده سيستم اندوكراين در بروز ناهنجاريهاى مادرزادى دئ

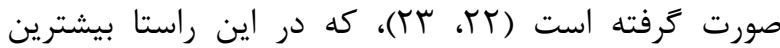
رويكرد نسبت به اثرات خاق كنندكى (Obsogenic) اين

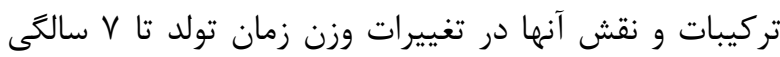

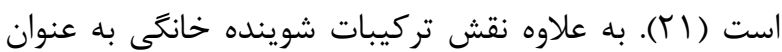
عوامل مختل كننده سيستم اندوكراين برروى سلامت نوزادان

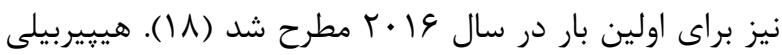
روبينمى نوزادان كه با تظاهرات بالينى زردى بعد از تولد بروز مى كند وضعيتى شايع و به ظاهر خوش خيم است، اما در

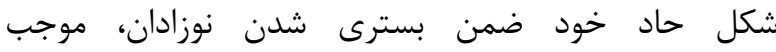

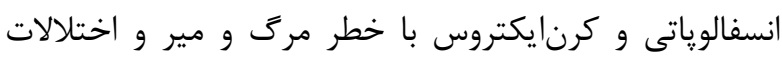
درازمدت سيستم عصبى همراه است(TF) كه دلايل مشخصى در خصوص بروز ايديوياتيك آن در نوزادان رسيده و فاقد ريسك فاكتورهاى شناخته شده تاكنون به انتشار نرسيده است. مشكل افزايش فزاينده زردى نوزادان در كشورهاى صنعتى و همين طور در كشورهاى در حال توسعه، مكررا در

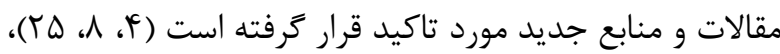

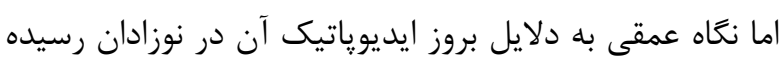

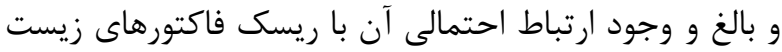
محيطى و سبك زندگى براى نخستين بار در سال ه1919 به

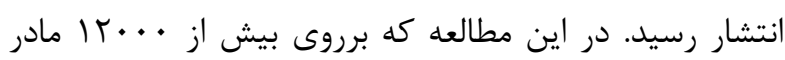

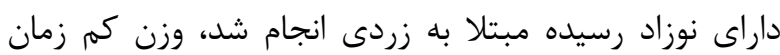
تولد، نزاد شرقى، خونريزى سه ماهه اول مادر و و كشيدن سيكار به عنوان عوامل اتيولوزيك بروز زردى مطرئ مطرح شدند

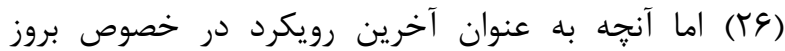
فزاينده اين رديده در نوزادان مدنظر قرار كرفته است، ارتباط علت معلولى قوى بين سطح بيلى روبين سرمى به عنوان يك فاكتور آنتى اكسيدان و ضد التهاب سرمى و محافظت كعنى كنيند در برابر بيمارىهاى ناشى از سموم از جمله ديابت، اختلالات كليوى، بيمارىهاى قلبى-عروقى و حتى مرك و مير است و

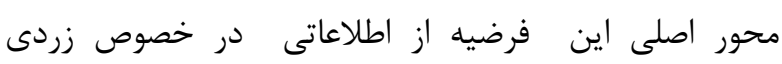


از تركيبات مهم ديكر موجود در خوش بو كنندههاى خانكى، بنزن است كه اگرجه ارتباط بين اين تركيب و متابوليتهايش

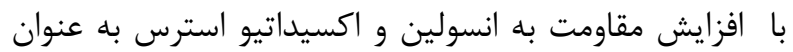

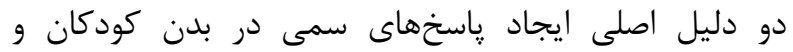
نوجوانان به طور جدى آترى مطرح شده است (Yr)، اما رابطه

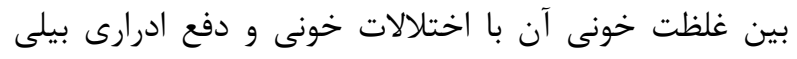
روبين نيز در جمعيت انسانى جين نيز اخيرا به انتشار رسيده

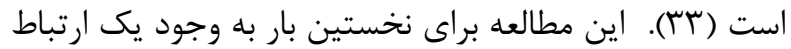
اوليه ولى بسيار قوى اين عوامل با افزايش ايديوياتيك بيلى إنى

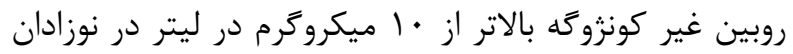

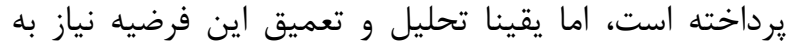
تعيين رابطه بين سطح خونى تركيبات آلى فرار مادر و نوزاد با باديا

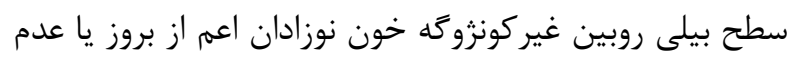
بروز علايم بالينى زردى دارد كه مىتواند جشئ جنم انداز ارزشمندى براى مطالعات آينده جهت تكميل فرضيه اوليه مطرح شده در اين تحقيق باشد. فاكتور ديخرى كه رابطه علت معلولى آن با افزايش بيلى روبين خون نوزادان مطرح شد، مصرف دترجنتهاى خانكَى با ماهيت

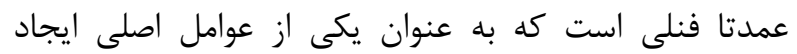

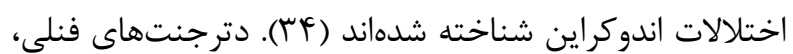
به عنوان اصلىترين عوامل مختل كننده سيستم اندوكراين

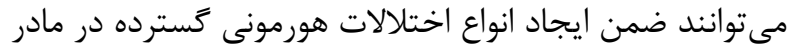

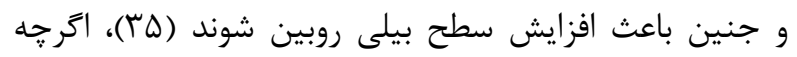
اين تحقيقات نيز عمدتا برروى مدلهاى سم شناسى آبزيان

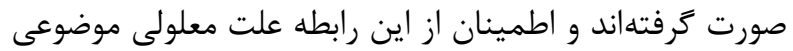

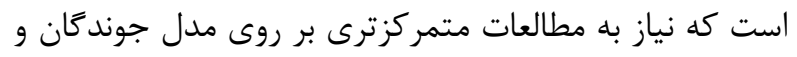
يافته إيدميولوزيك وسيعتر دارد. با اين حال اين اين رابطه

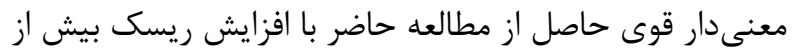

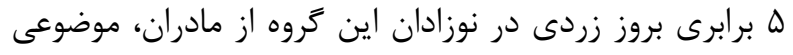

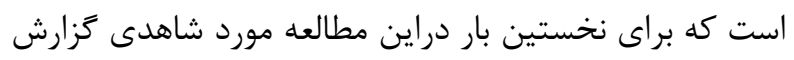

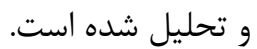
اين مطالعه مورد- شاهدى، براى نخستين بار نقش عوامل

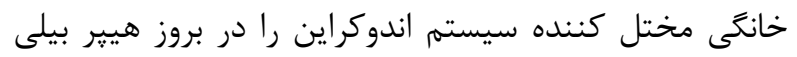

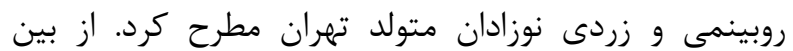
فاكتورهاى دموكرافيك مادران و نوزادان و فاكتورهان مثاى متعدد ديگر مرتبط با سبك زندَى مادران صرفا مصرف مداوم خوش فان

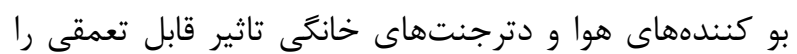
برروى افزايش ريسك اين يديده نشان داد. اكرجه مطالعات موجود مىتوانند توجيه كننده وجود رابطه علت معلولى بين عوامل مختل كننده سيستم اندوكراين و افزايش سطح بيلى
خوش بو كنندهاى هوا ( Air freshener) يكى از منابع اصلى داخلى مواجها با سموم مختل كننده سيستم اندوكراين از جمله تركيبات آلى (Endocrine Disrupting Chemicals) فرار (volatile organic compounds) محسوب مىشوند. مصرف اين تركيبات باعث افزايش جذب استنشاقى عوامل

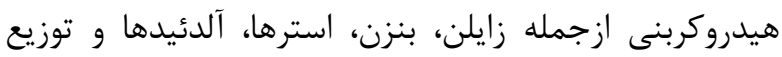

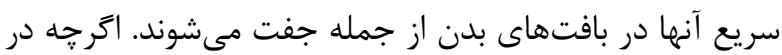

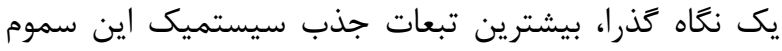

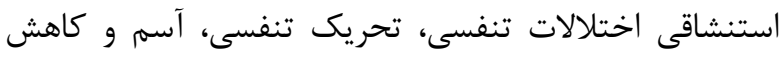

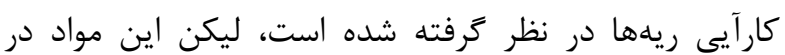
واكنش با ازون، آلايندههاى ثانويهاى از جمله فرمالدئيديد،

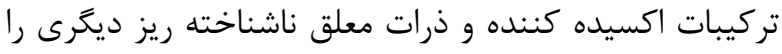

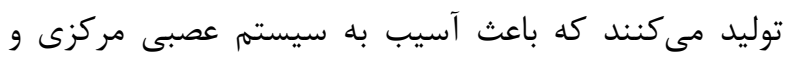
تغيير در سطح هورمونهاى بدن مىشوند (Y) و و اين مطالعه

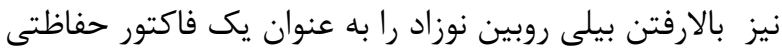

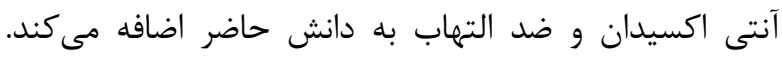
اكرجه اختلاف معنى دار مواجهه روزانه با خوش بو كنندههاى

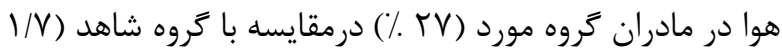

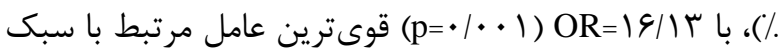
زندكى مادران در مقايسه با دها يارامتر سمى و غيرسمى ديكر از جمله مصرف سيكار، قليان، الكل، حشره كشها، سوابق توليد مثلى و عوامل دموكرافيك را مطرح كرده است،

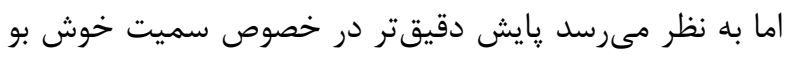
كنندهاى هواى موجود در بازارهاى كشور و ارتباط علت دئ

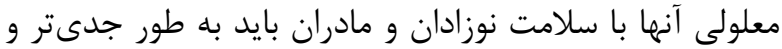

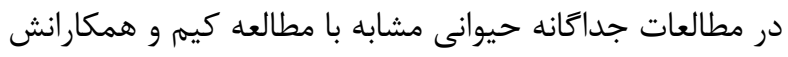

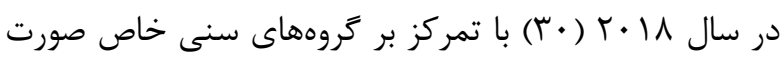
يذيرد. در مطالعات تخصصى سم شناسى با مدل حيوانى، اثر

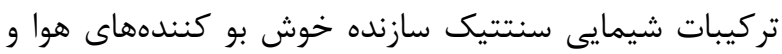

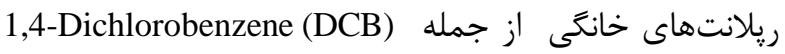
1,1-dichloro-2,2-bis(p-chlorophenyl) ethylene (p,p'- g 1,1,1-trichloro-2,2-bis(p- به عنوان متابوليت دائمى DDE) chlorophenyl)ethane استفاده دارند، برروى موش باردار بررسى شد و نشان داد كه جنين موش هندين برابر بيشتر در معرض اين آلايندها درا دران

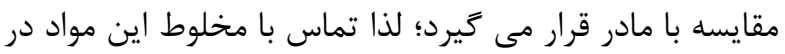
دوران باردارى به مراتب مىتواند خطرناكتر باشد( آس). مطالعه حاضر براى نخستين بار شواهد اوليه ناشى از نقش مواد مذكور را درزنان باردار تهرانى با سطح اقتصادى ضعيف مطرح كرد. 


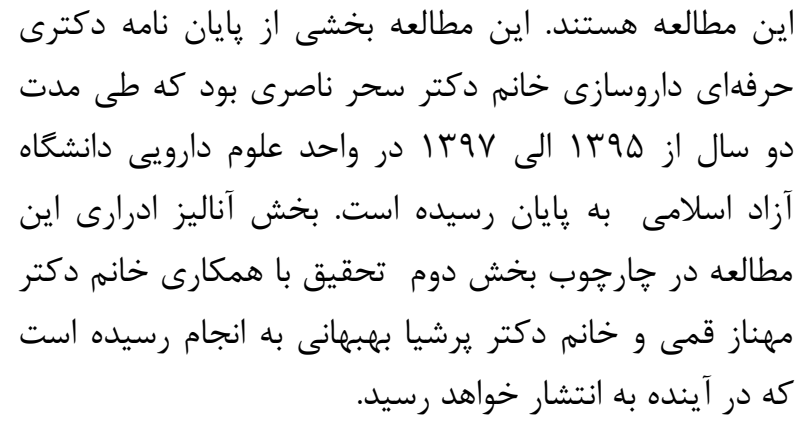

\section{REFERENCES}

1. Yu TC, Nguyen C, Ruiz N, Zhou S, Zhang X, Böing EA, Tan H. Prevalence and burden of illness of treated hemolytic neonatal hyperbilirubinemia in a privately insured population in the United States. BMC Pediatr 2019; 19: 53.

2. Tavakolizadeh R, Izadi A, Seirafi G, Khedmat L, Mojtahedi SY. Maternal risk factors for neonatal jaundice: a hospitalbased cross-sectional study in Tehran. Eur J Transl Myol 2018;28: 7618.

3. Ullah S, Rahman K, Hedayati M. Hyperbilirubinemia in Neonates: Types, Causes, Clinical Examinations, Preventive Measures and Treatments: A Narrative Review Article. Iran J Public Health 2016;45: 558-68.

4. Auger N, Laverdiere C, Ayoub A, Lo E, Luu TM. Neonatal phototherapy and future risk of childhood cancer. Int J Cancer 2019;145:2061-69.

5. Shahriarpanah S, Haji Ebrahim Tehrani F, Davati A, Ansari I. Effect of Phototherapy on Serum Level of Calcium, Magnesium and Vitamin D in Infants With Hyperbilirubinemia. Iran J Pathol 2018;3: 357-362.

6. D'Silva S, Colah RB, Ghosh K, Mukherjee MB. Combined effects of the UGT1A1 and OATP2 gene polymorphisms as major risk factor for unconjugated hyperbilirubinemia in Indian neonates. Gene 2014;547: 18-22.

7. Huang MJ, Kua KE, Teng HC, Tang KS, Weng HW, Huang CS. Risk factors for severe hyperbilirubinemia in neonates. Pediatr Res 2004;56:682-9.

8. Olusanya BO, Osibanjo FB, Slusher TM. Risk factors for severe neonatal hyperbilirubinemia in low and middle-income countries: a systematic review and meta-analysis. PLoS One 2015;10:0117229.

9. Kaveh M, Esmailnia T, Nayeri F, Nili F, Davari Tanha F, Ghajarzdeh M. UDP-glucuronosyltransferase promoter polymorphism in Iranian neonates with idiopathic hyperbilirubinemia. Acta Med Iran 2013;51:789-92.

10. Cayabyab R, Ramanathan R. High unbound bilirubin for age: a neurotoxin with major effects on the developing brain. Pediatr Res 2019;85: 183-190.

11. Tola HH, Ranjbaran M, Omani-Samani R, Sadeghi M. Prevalence of UTI among Iranian infants with prolonged jaundice, and its main causes: A systematic review and meta-analysis study. J Pediatr Urol 2018;14: 108-115.

12. Browne P, Noyes PD, Casey WM, Dix DJ. Application of Adverse Outcome Pathways to U.S. EPA's Endocrine Disruptor Screening Program. Environ Health Perspect 2017;125:096001.

13. Sifakis S, Androutsopoulos VP, Tsatsakis AM, Spandidos DA. Human exposure to endocrine disrupting chemicals: effects on the male and female reproductive systems. Environ Toxicol Pharmacol 2017;51:56-70.

14. Boas M, Feldt-Rasmussen U, Main KM. Thyroid effects of endocrine disrupting chemicals. Mol Cell Endocrinol 2012; 355:240-48.

15. Sidorkiewicz I, Zaręba K, Wołczyński S, Czerniecki J. Endocrine-disrupting chemicals-Mechanisms of action on male reproductive system. Toxicol Ind Health 2017;33:601-609.

16. Rattan S, Zhou C, Chiang C, Mahalingam S, Brehm E, Flaws JA. Exposure to endocrine disruptors during adulthood: consequences for female fertility. J Endocrinol 2017; 233: R109-29.

17. Velmurugan G, Ramprasath T, Gilles M, Swaminathan K, Ramasamy S. Gut Microbiota, Endocrine-Disrupting Chemicals, and the Diabetes Epidemic. Trends Endocrinol Metab 2017;28: 612-25. 
18. Ginsberg GL, Balk SJ. Consumer products as sources of chemical exposures to children: case study of triclosan. Curr Opin Pediatr 2016; 28: 235-42.

19. Diamanti-Kandarakis E, Bourguignon JP, Giudice LC, Hauser R, Prins GS, Soto AM, Zoeller RT, Gore AC. Endocrinedisrupting chemicals: an Endocrine Society scientific statement. Endocr Rev 2009; 30: 293-342.

20. Woods MM, Lanphear BP, Braun JM, McCandless LC. Gestational exposure to endocrine disrupting chemicals in relation to infant birth weight: a Bayesian analysis of the HOME Study. Environ Health 2017;16:115.

21. Agay-Shay K, Martinez D, Valvi D, Garcia-Esteban R, Basagaña X, Robinson O, et al. Exposure to EndocrineDisrupting Chemicals during Pregnancy and Weight at 7 Years of Age: A Multi-pollutant Approach. Environ Health Perspect 2015; 123: 1030-7.

22. Brits H, Adendorff J, Huisamen D, Beukes D, Botha K, Herbst H, Joubert G. The prevalence of neonatal jaundice and risk factors in healthy term neonates at National District Hospital in Bloemfontein. Afr J Prim Health Care Fam Med 2018;10:e1-6.

23. Mallozzi M, Bordi G, Garo C, Caserta D. The effect of maternal exposure to endocrine disrupting chemicals on fetal and neonatal development: A review on the major concerns. Birth Defects Res C Embryo Today 2016; 108: $224-242$.

24. Olusanya BO, Kaplan M, Hansen TWR. Neonatal hyperbilirubinaemia: a global perspective. Lancet Child Adolesc Health 2018; 2: 610-20.

25. Kang X, Tu H, Tian T, Huang Z, Luo L, Shen L, Ye J. Home environment and diseases in early life are associated with allergic rhinitis. Int J Pediatr Otorhinolaryngol 2019;118:47-52.

26. Linn S, Schoenbaum SC, Monson RR, Rosner B, Stubblefield PG, Ryan KJ. Epidemiology of neonatal hyperbilirubinemia. Pediatrics 1985; 75: 770-4.

27. Coltell O, Asensio EM, Sorlí JV, Barragán R, Fernández-Carrión R, Portolés O, et al. Genome-Wide Association Study (GWAS) on Bilirubin Concentrations in Subjects with Metabolic Syndrome: Sex-Specific GWAS Analysis and GeneDiet Interactions in a Mediterranean Population. Nutrients 2019;11: E90.

28. Lin CC, Chien CJ, Tsai MS, Hsieh CJ, Hsieh WS, Chen PC. Prenatal phenolic compounds exposure and neurobehavioral development at 2 and 7years of age. Sci Total Environ 2017; 605: 801-810.

29. Kim S, Hong SH, Bong CK, Cho MH.Characterization of air freshener emission: the potential health effects. J Toxicol Sci 2015; 40: 535-50.

30. Kim JH, Lee D, Lim H, Kim T, Suk K, Seo J. Risk assessment to human health: Consumer exposure to ingredients in air fresheners. Regul Toxicol Pharmacol 2018; 98: 31-40.

31. Makita Y. Effects of perinatal, combined exposure to 1,4-dichlorobenzene and 1,1-dichloro-2,2-bis(pchlorophenyl)ethylene on rat female reproductive system. Basic Clin Pharmacol Toxicol 2008;102:360-4.

32. Amin MM, Rafiei N, Poursafa P, Ebrahimpour K, Mozafarian N, Shoshtari-Yeganeh B, et al. Association of benzene exposure with insulin resistance, SOD, and MDA as markers of oxidative stress in children and adolescents. Environ Sci Pollut Res Int 2018; 25: 34046-052.

33. Li X, Guo Y, Song X, He Y, Zhang H, Bao H, et al. A cross-sectional survey based on blood VOCs, hematological parameters and urine indicators in a population in Jilin. Northeast China. Environ Geochem Health 2019; 41: 1599-615.

34. Monneret C. What is an endocrine disruptor? C R Biol 2017; 340: 403-405.

35. Senthil Kumaran S, Kavitha C, Ramesh M, Grummt T. Toxicity studies of nonylphenol and octylphenol: hormonal, hematological and biochemical effects in Clarias gariepinus. J Appl Toxicol 2011; 31: 752-61.

36. Zhou J, Yang C, Zhu W, Chen S, Zeng Y, Wang J, Zhao H, Chen Y, Lin F. Identification of Genetic Risk Factors for Neonatal Hyperbilirubinemia in Fujian Province, Southeastern China: A Case-Control Study. Biomed Res Int 2018; 2018: 7803175. 